\title{
THEORETICAL INVESTIGATION OF PRESSURE DISTRIBUTION IN A MULTI-TYPAL TRANSPORT UNIT
}

\author{
Olena NALOBINA ${ }^{1 *}$, Yulia MURAVUNETS ${ }^{2}$, Alexander GERASIMCHUK ${ }^{2}$, \\ Vitaly PUTS ${ }^{2}$, Alexander SHOVKOMYD ${ }^{2}$ \\ ${ }^{1}$ National University of Water Management and Nature Resources Use, Ukraine \\ ${ }^{2}$ Lutsk National Technical University, Ukraine
}

\begin{abstract}
This article presents the results from the theoretical research of tension loading in a channel of fixing conveyor of the apparatus for flax beating and scutching. The analyses of literature have shown that the quality of flax fibre greatly depends on the conditions of retted straw processing by means of breaking-scutching machines, namely on machine parameters, operating regimes and design characteristics. There are considerable high fibre losses due to inappropriate fixing of straw in the conveyor canal; percentage of these losses is much higher than losses caused by any other reasons. The paper presents equations for calculation of pressure inside the conveyor canal of apparatus for flax breaking and scutching. It investigates the regularities of pressure loading in the sectors which fix the straw according to the aforementioned equation. Research shows that the highest pressure occurs in the area opposite the press-rolls axis; it decreases when distancing from it. Research also shows that pressure in the axis zone is lower when the belt tension and spring compression are low. This pressure loading causes pulling of the strands from the conveyor canal and fibre losses. These theoretical regularities can be utilized for calculation of the fixation force to secure the retted straw between belts in order to reduce the losses.
\end{abstract}

Keywords: flax; breaking-scutching apparatus; fixing conveyor; retted straw; pressure; losses

Nowadays, Ukraine belongs to significant agricultural countries of Europe and the world which has the necessary capacity for production of strategic food products (Baranovsky et al., 2017). Situation with flax is similar - flax production is in high demand, especially on European and American market. Agricultural flax production is ecologically profitable, since it is a renewable and ecologically clean product (Foulk et al., 2008). Industries use flax to get fibre, seeds and other products (Komlajeva and Adamovičs, 2011; Anthony, 2005; Kulma et al., 2015). Flax fibre is a natural resource for wide variety of technical and household goods (Kessler and Kohler, 1996; Foulk et al., 2000).

Flax growing and processing has a long history in Ukraine. Nowadays, different agricultural enterprises produce flax in Ukraine. They are of different property categories, work without coordination and are not connected into united process chain. It is necessary to unite different branches of flax manufacturing, determine the essential technical and technological factors influencing the production quality and creating favourable conditions for production of high quality and competitive flax products, because this sphere is important and promising.

Quality of flax fibre greatly depends on the breakingscutching process conditions - machine parameters, operating regimes and design characteristics of the equipment (Markov, 1981; Barinov et al., 2009; Akin et al., 2005). Scutching represents the final stage of straw processing. It is characterized by serious losses of fibre contained in retted straw. During the scutching process, conveyor belts fix a certain amount of material and beater blades process it. Fixing transporter should secure the flax straw layer in order to avoid pulling. However, multiple researches (Pashyn, 1999; Kovalenko et al., 2005; Nalobina, 2016) have confirmed that the transporter does not fix the straw layer adequately. It has a negative impact on machine functioning and straw processing becomes less technically and economically beneficial. Imperfect straw fixation in the conveyor canal causes significant losses in long fibre when processing by means of apparatus for breaking and scutching. The losses reach 9.4\% (Lapshyn, 2002). Due to this reason, we consider it necessary to observe rigorously the fixing conveyor and the process of straw fixation.

\section{Material and methods}

This paper presents the results of theoretical research. The main research purpose is to obtain the regularities for calculation of pressure in the fixing conveyor canal of apparatus for breaking and scutching. Other aims are to observe the regularities of tension distribution in the sectors where the straw is fixed, to determine the reasons of fibre losses during the breaking process on the basis of the aforementioned regularities. For this purpose, basics 
of theoretical mechanics, belt-drive theory, power theory, computer calculations and programs to perform this research were utilized to achieve these goals.

Fig. 1 shows the scheme of fixing conveyor in apparatus for breaking and scutching. Fixing rolls [3] are located above the belt working unit. Retted straw is fixed between two belts; Fig. 2 shows the profile.

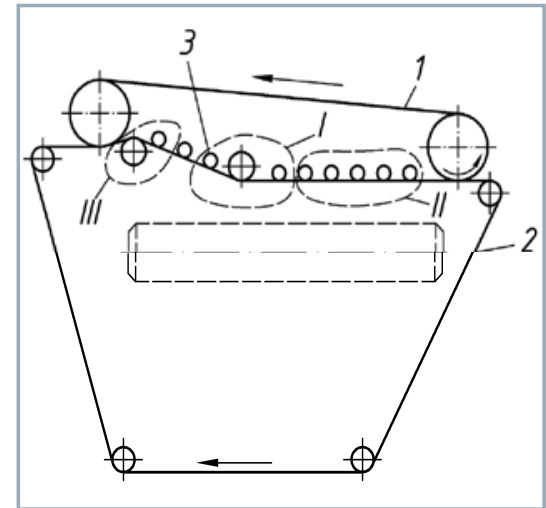

Fig. 1 Scheme of fixing conveyor in the breaking and scutching apparatus

1 - upper belt; 2 - lower belt; 3 fixing rolls; I - straight area; II, III inclined areas of the working unit

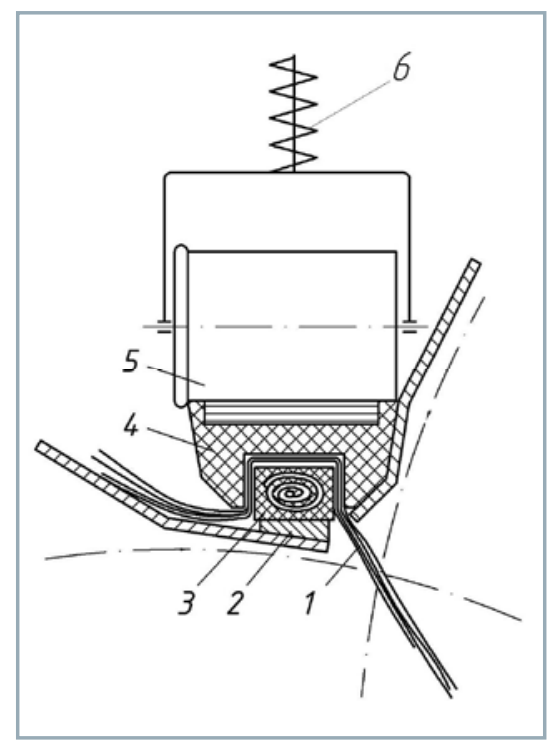

Fig. 2 Fixing conveyor profile view 1 - retted straw; 2 - flute; 3 - lower belt; 4 - upper belt; 5 - fixing roll; 6 - roller spring

The upper belt creates the pressure in areas in which the rolls press most. Fig. 3 shows the scheme of conveyor unit with two press rolls with centres $O$ and $O_{1}$. The arc $a b$, formed by the upper belt deformation due to the press roll pressure, is not essential. Belt element within the arc $a b$ has been selected for these purposes; central angle $d \alpha$ corresponds with it.

Following forces influence this element:

- tension force of the upper belt $F$;

- tension force with extra belt prolongation caused by the straw layer $F+d F$;

- friction force $F_{f}=f \cdot d N$, where $f$ represents the belt material friction coefficient;

- normal reaction of the retted straw layer $d N$;

- reaction of the press roll surface $d R_{p}$;

- reaction of the lower belt $d R_{H}$.

The system of coordinates with chosen element is connected and its equilibrium equation is as follows:

$$
\left.\begin{array}{l}
\sum X_{i}=-F+(F+d F)-f d N=0 \\
\sum Y_{i}=d R_{p}-d R_{H}-F \frac{d \alpha}{\alpha}-(F+d F) \frac{d \alpha}{\alpha}=0
\end{array}\right\}
$$

The lower belt reaction is $d R_{H}=d R_{v}=F \cdot d \alpha$. Taking into consideration that $\sin \frac{d \alpha}{\alpha} \approx d \alpha$ and $\cos \frac{d \alpha}{\alpha} \approx 1$, we get:

$$
\frac{d F}{d \alpha}-f \times F=0
$$

From the drive-belting theory (Ivanov, 1984), we know that $F=F_{0} \cdot e^{f^{\prime} \alpha}$, where $F_{0}$ is a minimum force that occurs in the sectional view of the belt when it "circles" the roll. When angle $\alpha^{0}$ changes from 0 (point $a$ ) to $\alpha$, force $F$ will also change from $F_{a}$ to $F$. Taking this into account:

$$
F=F_{\alpha} e^{-f^{l} \cdot \alpha}
$$

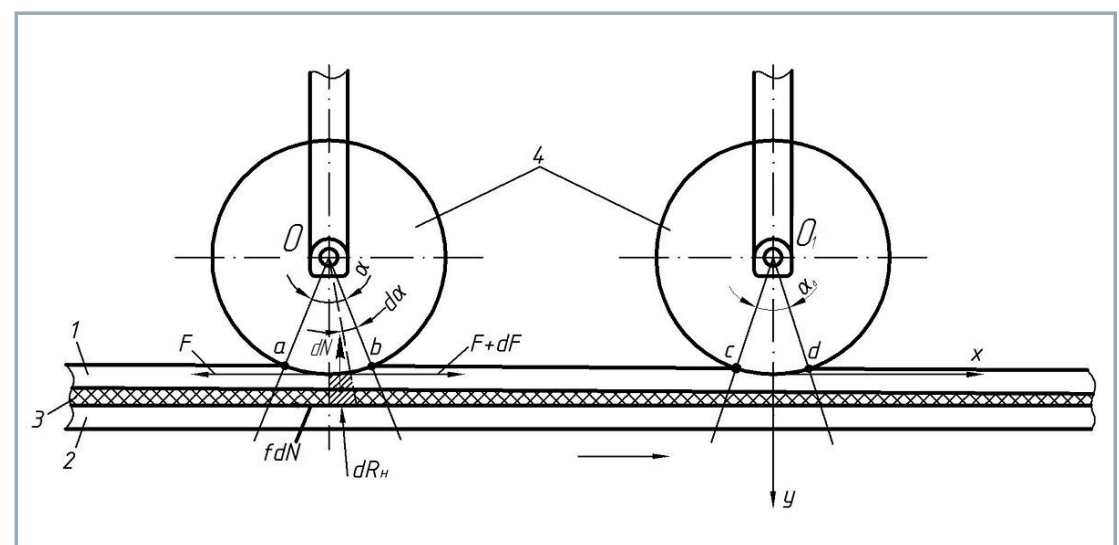

Fig. 3 Scheme of pressure caused by fixing rolls upon the belt 1 - upper belt; 2 - lower belt; 3 - layer of the retted straw; 4 - rolls

In regards to aforementioned, by integration of Eq. (2), we get:

$$
F=F_{\alpha}+F e^{-f / \alpha}
$$

Using Eq. (4), it is possible to calculate the tension. It is possible to calculate the pressure taking into account that $p=\frac{F}{S}$, where $S$ is contact surface:

$$
p=\frac{F_{\alpha}+F e^{-f / \alpha}}{b r}
$$


where:

$\begin{array}{ll}b & - \text { belt width, } \mathrm{mm} \\ r & - \text { roll radius, } \mathrm{mm}\end{array}$

Eq. (5) is valid for areas III and I (Fig. 1). Furthermore, it is possible to calculate the pressure on the straight area (area II in Fig. 1). If rubber is pressed (Tymoshenko, 1979), the pressure equals:

$$
g=c \cdot \Delta
$$

where:

c - rubber density, $\mathrm{H} \cdot \mathrm{mm}^{-3}$

$\Delta \quad$ - depth of the upper belt shrinking with the roll, $\mathrm{mm}$

Subsequently, interaction between the roll and the upper belt can be examined in the following scheme (Fig. 4).

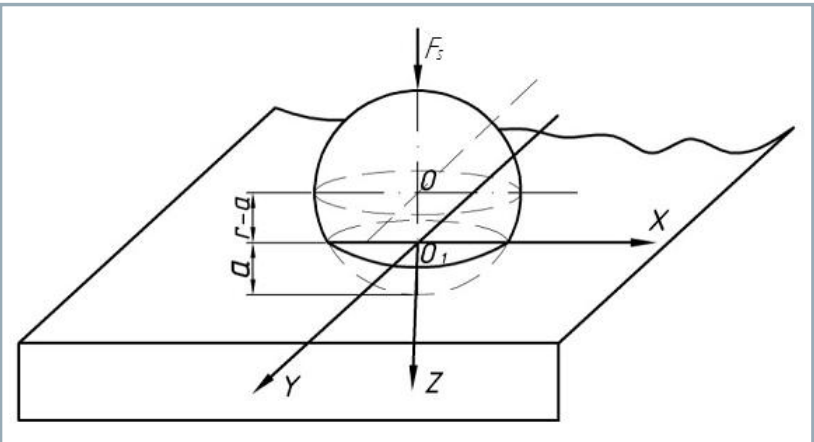

Fig. 4 Scheme of interaction between the roll and the upper belt

The roll is pressed to the upper belt by adjusting the spring [6] (Fig. 2). If the roll spring shrinks, it begins to press the belt, which deforms ( $a$ is deformation). Vertical component of the belt reaction equals: $c \cdot d x \cdot d y \cdot z$, accordingly, $F_{S}$ equals:

$$
F=\iint_{\theta} c_{2} z d x \cdot d y
$$

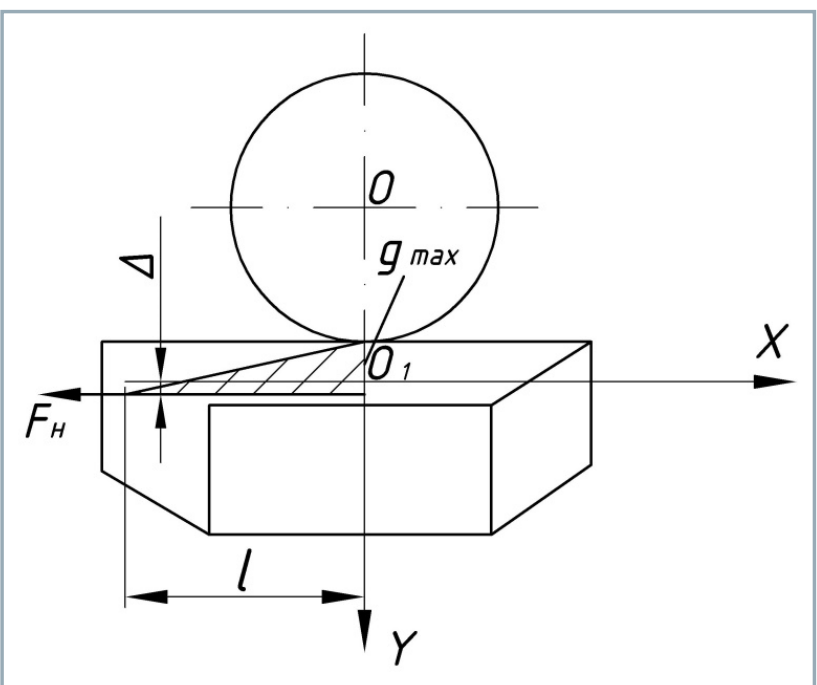

Fig. 5 Scheme of the belt deformation in the straight area where:

$\theta \quad$ - the circumference of the circle that we get when the $X O Y$ subspace crosscuts the roll. Belt deformation $a$ is not essential, that is why $a / d_{p}$ ratio will be a small number $\left(d_{p}\right.$ is the diameter of the roll). Dependence of $\Delta$ (Fig. 5) from the distance $x$ relative to the point $O$ (to the right and to the left) is $\Delta x \approx \Delta \cos \frac{\pi}{2 l} x$, where $I$ - length of the pressing zone, $x$ - running point at which the pressure is measured

Necessary force for pressing the straw strand can be calculated according the following formula:

$$
F_{p r}=2 \int_{0}^{l} b c \Delta x d x=\frac{4}{\pi} l b c \Delta
$$

Equation for the line, on which the tension force $F_{H}$ acts (Fig. 5):

$$
y \approx \Delta\left(1-\cos \frac{\pi}{2 l} x\right)
$$

In accordance with the belt theory (Ivanov, 1984), differential equation of the deflection belt line is:

$$
E I=\frac{d^{2} y}{d x^{2}}=-F(\Delta-y)+M
$$

where:

E - elasticity modulus of belt material

I - second area moment of the upper belt respective the neutral axis

M - curving moment that can be calculated as follows: $b c \int_{x}^{a} \Delta x\left(x-x_{i}\right) d x$, where $x_{i}$ is abscissa of $i$-cut

Taking into consideration that $g=c \Delta x$, we get:

$$
\begin{gathered}
y=-\frac{4 I^{2} \Delta}{\pi E I}\left(F_{H}+\frac{4 I^{2} b c}{\pi^{2}}\right)\left(1-\cos \frac{\pi}{2 l} x\right)-{ }^{l b c} \pi E I \\
-\frac{l b c \Delta}{3 \pi E I} x^{3}+\frac{I^{2} b c \Delta}{\pi E I} x^{2}
\end{gathered}
$$

If we assume that abscissa $x$ equals / and ordinate equals deformation $\Delta$, we can obtain the length of the area in which the deformation / spreads:

$$
I=\sqrt{\frac{F_{H}+\sqrt{F_{H}^{2}+1.2 b c E I}}{0.24 b c}}
$$

\section{Results and discussion}

Taking into account the mathematical dependences, received mathematical dependence allows determination of the pressure of the upper pass on the lower in the area of the roller:

$$
g_{x} \approx \frac{0.4 F_{H}}{b c\left(F_{H}+\sqrt{F_{H}^{2}+1.2 b c E l}\right)} \cdot\left(1+\cos \frac{\pi}{2 l} x\right)
$$


If tensions of the upper and lower belts are different, variable $\mathrm{F}$ should be substituted by the smaller figure in Eq. (13).

Calculations using the Eq. (13) were performed by means of Mathad software. Variables were $F_{H}$ and $x$.

Fig. 6 shows the graphs of pressure loading in the roller zone and outside of it; the roller is pressed against the belt at different forces.
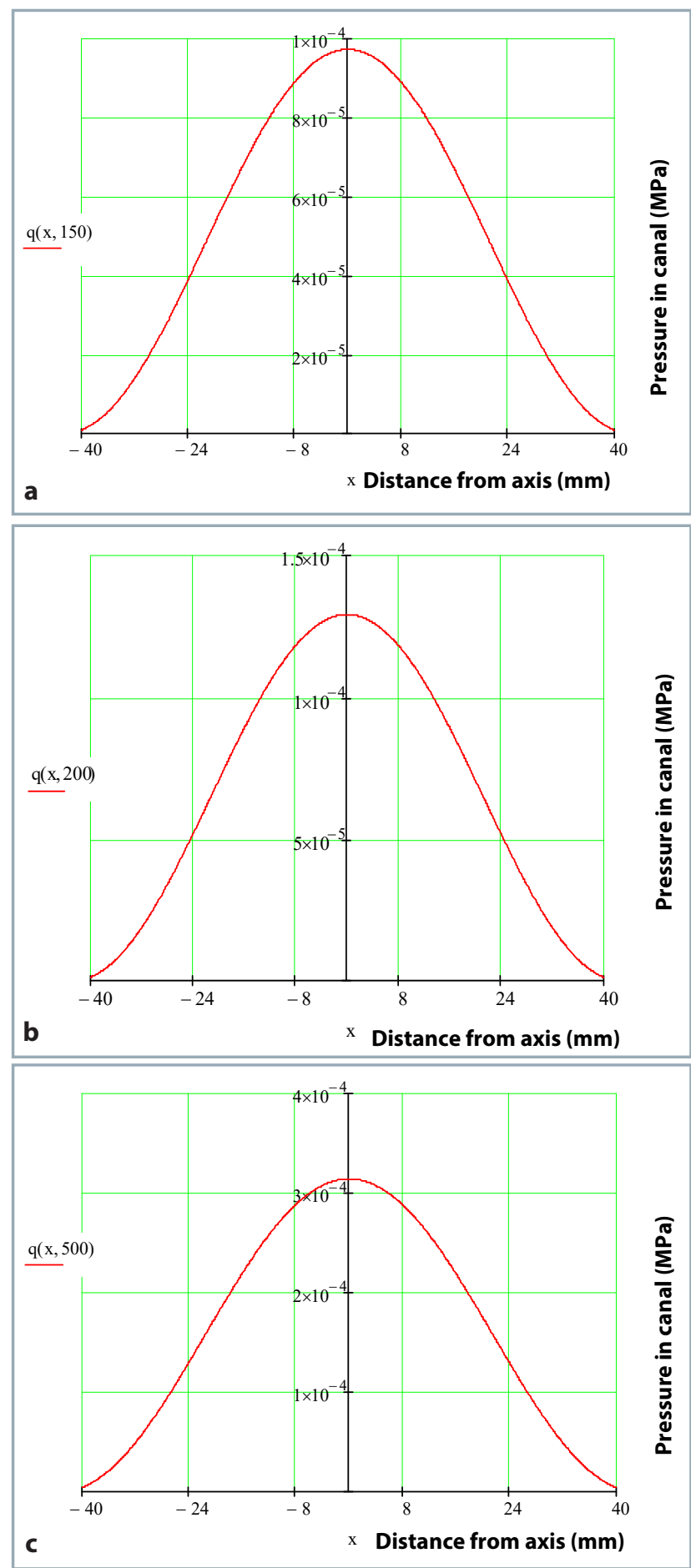

Fig. 6 Graphs of the pressure changes depending on the distance from the axis and the point of measurement, with spring shrinking force of $150 \mathrm{H}, 200 \mathrm{H}, 500 \mathrm{H}$
Fig. 6 shows that pressure is maximal against the fixing rolls axis. It decreases when the distance from axis increases. Furthermore, the smaller the belt tension and spring tension are the lower the pressure in the axis zone.

Taking into account the obtained results from theoretical investigation on the distribution of pressure in the flask of clamping conveyor, we will form the hypothesis of further research on the functioning of this working body. Improvement of the clamping conveyor construction should be carried out in the following directions:

- optimization of parameters of clamping rollers;

- determining the optimal distance between the rollers' axes.

The first direction involves solving of two problems:

1. to prove the rational diameter of the roller, which would enable to create the necessary pressure in the conveyor duct and thus ensure a materialsaving construction;

2. to substantiate the configuration of the clamping roller, which would ensure a uniform clamping of strings both along the length and the width of the clamp mower conveyor.

It is expedient to determine the above parameters on the basis of the experimental research.

\section{Conclusion}

The authors have found the formulas for calculation of force necessary for retted straw fixing - Eq. (8); the length of the area in which deformation spreads - Eq. (12); the pressure of the upper belt upon the lower belt in the roller zone - (Eq. (13). These regularities have been established for the very first time. They allow calculation of the necessary force for pressing rollers according to the conveyor belt parameters. Adequate force choice will ensure the retted straw fixation and decrease the fibre losses.

Research has shown that the irregular tension loading in the conveyor canal is a reason for retted straw losses during the breaking process. The graphs show that pressure is almost absent in areas far from the axis and strands are pulled out causing fibre losses.

\section{References}

ANTHONY, W. S. 2005. Development of machines to separate fiber and shive from seed flax straw. In Applied Engineering in Agriculture, vol. 21, no. 6, pp. 1057-1063.

AKIN, D. E. - DODD, R. B. - FOULK, J. A. 2005. Pilot plant for processing flax fiber. In Industrial Crops and Products, vol. 21, no. 3, pp. 369-378.

BARANOVSKY, V. - DUBCHAK, N. - PANKIV, M. 2017. Experimental research of stripping the leaves from root crops. In Acta Technologica Agriculurae, vol. 20, no. 3, pp. 69-73.

BARINOV, A. A. - MAJANSKYI, S. E. - PASHYN, E. L. 2009. Optimal flax layer position during breaking and scutching process. In Technology of Textile Industry, vol. 313, no. 1, pp. 31-34. (In Russian: Optimizatsja raspolozhenija Inianogo sloja pri pererabotke na mialno-trepalnom agregate).

FOULK, J. - AKIN, D. - DODD, R. 2008. Processability of flax plant stalks into functional bast fibers. In Composite Interfaces, vol. 15, no. $2-3$, pp. 147-168. 
FOULK, J. - AKIN, D. - DODD, R. 2000. New low cost flax fibers for composites. In "Proc. of the Society for Automotive Engineering International Congress \& Exposition", SAE Technical Paper 2000-011133, vol. 1, pp. 1-13.

IVANOV, M. N. 1984. Machine Details. Moscow: High School, 336 pp. (In Russian: Detali mashyn).

KESSLER, R. W. - KOHLER, R. 1996. New strategies for exploiting flax and hemp. In Chemtech, vol. 12, pp. 34-42.

KOMLAJEVA, L. - ADAMOVIČS, A. 2011. The perspective of Latvian flax (Linum usitatissimum) for biofuels. In Agronomy Research Biosystem Engineering special issue 1, pp. 107-113.

KOVALENKO, N. I. - MUZOLEVSKII, V. A. - RUSSU, E. A. 2005. Research of the fiber layer fixing force in the transporting belt of the scutching machine. In Annals of Kostroma State Technological University, no. 1, pp. 12-16. (In Russian: Issledovanie usilia zazhyma sloja volokna $v$ transportujuschem remne trepalnoj mashyny).

KULMA, A. - ZUK, M. - LONG, S. H. - QIU, C. S. - WANG, Y. F. JANKAUSKIENE, S. - PREISNER, M. - KOSTYN, K. - SZOPA, J. 2015 Biotechnology of fibrous flax in Europe and China. In Industrial Crops and Products, vol. 68, pp. 50-59.
LAPSHYN, A. B. 2002. Development of the theory of processed flax fiber [Doctor of Engineering thesis]. Kostroma, 401 pp. (In Russian: Razvitie teorii protsessa poluchenia trepanogo Inianogo volokna). MARKOV, V. V. 1981. Primary Conversion of Flax and Other Fiber Crops. Moscow : Consumer Goods and Food Industry, 376 pp. (In Russian: Pervichnaja obrabotka Ina I drugih lybianyh kultur).

NALOBINA, E. A. 2016. Research of the ways to improve the quality of flax straw and retted straw. In Motrol, vol. 18, no. 4, pp. 45-49. (In Russian: Issledovanie napravlenij povyshenija kachestva solomy i tresty Ina-dolguntsa).

PASHYN, E L. 1999. Forming of long fiber yielding during process of flax stems with machine for breaking and scutching. In Annals of Universities. Technology of Textile Industry, no. 3, pp. 24-27. (In Russian: Formirovanie vyhoda dlinnogo volokna pri obrabotke steblej Ina na mjalno-trepalnom aggregate).

TYMOSHENKO, S. P. 1979. Course of Elasticity Theory. Kiev : Scientific Thought, 501 pp. (In Russian: Kurs teorii uprugosti). 